\title{
Insight into Commuters:
}

Research on the Behavior and Mind of Consumers in Transit

\section{移動者インサイト}

\section{一 移動中の生活者, その行動と心理に関する研究 一}

\author{
Shinji Takahashi ${ }^{* 1}$, Yasunari Sasaki ${ }^{* 2}$ \\ 株式会社 JR 西日本コミュニケーションズ \\ コミュニケーション・プランニング部 \\ 株式会社 JR 西日本コミュニケーションズ \\ コミュニケーション・プランニング部
}

高橋 伸治
佐々木 康成

\footnotetext{
${ }^{* 1}$ Communication Planning Division, West Japan Marketing Communications, Inc., s-takahashi@jcomm.co.jp

*2 Communication Planning Division, West Japan Marketing Communications, Inc., y-sasaki@jcomm.co.jp
}

\begin{abstract}
In this study, commuters refer to consumers that use transit, especially train. They include railway users, consumers shopping in or near the stations and the audience for out-of-home $(\mathrm{OOH})$ advertising and traffic advertising. While the commercial environment around the stations is increasingly fulfilling, and the information environment in transit is changing rapidly due to the spread of smartphone and digital signage, commuters are becoming important potential consumers and targets of communication. The aim of this research is to improve service in the stations and the facilities around said stations and to find effective ways to communicate with commuters by understanding their behavioral and psychological characteristics.
\end{abstract}

Keyword : Hedonic consumption in transit, Smartphone use and consumption behavior in transit, Desire for leisure, True feelings of commuters

要約：「移動者」とは通勤や通学で移動中の生活者のことで, 本研究では主に鉄道を利用して通勤する「移動者」を対象とする。 その「移動者」は鉄道利用者であり，駅ナカや駅チカで買物をする消費者であり，OOH や交通広告のオーディエンスであるが， 駅周辺の商業環境が益々充実化し, またスマートフォンやデジタルサイネージの普及により移動中の情報環境が急激に変化する 中，潜在ショッパーとしての「移動者」、コミュニケーションターゲットとしての「移動者」が重要な存在になってきている。 本研究の狙いはそういった「移動者」の行動特性と心理特性を捉え, それを駅や駅周辺施設のサ一ビス向上や「移動者」との効 果的なコミュニケーション手法の開発に結びつけることである。

キーワード : 移動中の快楽消費, 移動中のスマホ利用と消費行動, 移動者の安楽欲求, 移動者の「ホンネ」

Information : Received 12 August 2019; Accepted 13 November 2019

\section{I. 問題認識と調査の概要}

本研究は生活者を「移動中」という TPO で捉えた消費 者行動の応用研究である。そしてその目的は鉄道を利用 して通勤する移動者の行動と心理を捉えることであり， 移動シーンにいる生活者にはその属性に関わらず共通し た心理特性があるという仮説を前提としている。移動空 間における商業環境が益々充実化し情報環境が急激に変
化する中, 移動者とのコミュニケーションによってその 消費行動に影響を与える可能性が大きく広がってきてい る。そしてそのコミュニケーションを効果的に行うため には，まずは移動者の本音のニーズを知ることが必要で ある。

本研究は 2016 年から 2017 年にかけて 4 回の定性調査 を実施し，そこで抽出した仮説を定量調査で検証すると いうプロセスで行い，本稿はその計 5 回の調査結果をも とに分析を行ったものである。定性調査については，ま 
ず初めに生活者が移動中にどのような「気づき」を得て いるかを調べ移動者の心理的状況を大まかに捉えるとと もに，生活者にとって移動空間とはどういったものであ るのかを探り，次に移動者の「所作」を観察し生活者が 移動時間をどのように過ごしているかを捉えることで, その背景にある無意識の思考や感情を探るとともに現代 の生活者にとっての移動時間の意味合いを考察した。そ の上で 3 回目には「移動中の買物行動」, 4 回目には「移 動中のスマホ利用行動」といったテーマで, 本研究の焦 点となる消費行動やコミュニケーション行動に関する調 查を行い，そこから各々の行動の背景にある事情や状況 を洞察しながら意識や心理に関する仮説を導き出した (表 1)。そしてこれらの定性調査から得た仮説を定量調 查によって検証した（表 2）。

\section{II．調査結果の概要と主な発見}

\section{1. 移動中の行動}

「移動者がしていること」や「移動者に起こっているこ と」を日記調查や行動観察によって,「気づき」,「所作」,
「買物」「「マホホ利用」といった側面から洗い出し, それ を定量調查で検証した。

はじめの「移動中の気づき」に関する調査では，「他人 の迷惑行為」,「季節の変化」,「自分の体調変化」,「街の 様子の変化」「レジャーの広告」などが多くの移動者に共 通する「気づき」の対象であることがわかった（図1-1)）。 また移動者はいろいろな考え事をしているが，その多く が「気づき」に紐づいていた。そして次の休日の予定や 将来のこと, 最近の出来事や昔のことなど, 過去や未来 に思いを巡らせている状況が多く見られ，生活者は移動 中に「マインドワンダリング」といわれる頭がぼんやり した状態になり，こうした「メンタルタイムトラベル」 をしていると思われる（図 1-2)（Corballis（1843）によ ると、「マインドワンダリング」とは頭がぼんやりした状 態のことで，人はそういった状態の時，時間を遡ったり 進めたりといった「メンタルタイムトラベル」をしてい るという)。

生活者は様々なメデイアから情報を得て世の中の動き や流行を知るが，それらの対象物や事象を移動中にリア ルに見たり触れたりすることで，それを実感している状 況が窺われた。テレビやインターネットなどのメデイア

\section{表 1 定性調查概要}

\begin{tabular}{|c|c|c|c|c|}
\hline テーマ & 調査目的 & 調査方法 & 調査時期 & 調査対象者 \\
\hline $\begin{array}{c}\text { 移動中の気づきと } \\
\text { インサイト }\end{array}$ & $\begin{array}{l}\text { 移動中の気づきや関心事を捉え } \\
\text { そこから移動者心理を洞察 }\end{array}$ & $\begin{array}{l}\text { MROC } \\
\text { (エムロック) }\end{array}$ & 2016年7～8月 & $\begin{array}{l}\text { 京阪神在住の会社勤めをする } \\
20 \text { 代, } 30 \text { 代の男女 } 20 \text { 名 }\end{array}$ \\
\hline $\begin{array}{l}\text { 移動中の所作と } \\
\text { インサイト }\end{array}$ & $\begin{array}{c}\text { 移動中の振る舞いや仕草を観察し } \\
\text { そこから移動者心理を洞察 }\end{array}$ & 行動観察調査 & 2017年1～2月 & $\begin{array}{l}\text { 電車内や駅構内にいる人(会社 } \\
\text { 勤めをしていると思われる人) }\end{array}$ \\
\hline $\begin{array}{l}\text { 移動中の買物と } \\
\text { インサイト }\end{array}$ & $\begin{array}{l}\text { 移動中の買物行動を捉え } \\
\text { そこから移動者心理を洞察 }\end{array}$ & $\begin{array}{l}\text { 買物日記調査 \& } \\
\text { デプスインタビュー }\end{array}$ & 2017年5～6月 & $\begin{array}{l}\text { 京阪神在住の会社勤女をする } \\
20 \text { 代から } 50 \text { 代の男女 } 10 \text { 名 }\end{array}$ \\
\hline $\begin{array}{l}\text { 移動中のスマホ利用 } \\
\text { とインサイト }\end{array}$ & $\begin{array}{l}\text { 移動中のスマホ利用行動を捉え } \\
\text { そこから移動者心理を洞察 }\end{array}$ & $\begin{array}{l}\text { スマホ日記調査\& } \\
\text { デプスインタビュー }\end{array}$ & 2017 年11 12月 & $\begin{array}{c}\text { 京阪神在住の会社勤めをする } \\
20 \text { 代, } 30 \text { 代の男女 } 8 \text { 名 }\end{array}$ \\
\hline
\end{tabular}

調查目的 調查方法 調查期間 調查対象者 サンプル数
4 回の定性調査で抽出した移動者の行動特性，心理特性に関する仮説の検証 webアンケート調查（設問数/スクリーニング調查 : 5 問, 本調查 : 80 問)

スクリーニング調查 : 2018 年 11月 28 日〜29日，本調查：2018 年 11月30日〜 12 月 5 日 京阪神在住の会社勤めをする20代から50 代の男女。通勤で週 5 回 (月曜〜金曜) 鉄道を利用している人 スクリーニング調查 : 30,000 , 本調査 : 500 
で得る気づきが「認知的気づき」であるのに対して移動 中のそれは「実感的気づき」であり，すなわち生活者に とって移動空間とは「実感的気づき」を得る機会である といえる。そしてその「気づき」は実感的であるが故に その後の行動につながることも多いと思われる。

次に実施した行動観察調査では駅のホームや電車でス マホ操作しながら資料を読んだり書き込みをしたりと いったように忙しく活動する移動者の所作が多く見られ， 現代の生活者にとって移動時間は「つぶすもの」から「使 うもの」に変わってきていることが窺われた。また混雑 した電車で「パーソナルスペース」が確保できずに不快 感を紛らわそうとする移動者や，イヤホンを耳栓替わり にして「カプセル人間」になって自分の世界に入り込む 移動者の様子なども多く観察された（図 2-(1), (2)）。 Nakano（1997）によると「カプセル人間」とはメディア によって周囲を遮断する人のことで, 会社や家庭では中々 自分の時間を持てない生活者が移動中に「カプセル人間」 になって一人の時間を過ごしているということである。 また他人がいると落ち着かない個人の空間のことを「パー

\section{図 1-1)＼cjkstart移動中の気づきや関心ごとの主な対象}

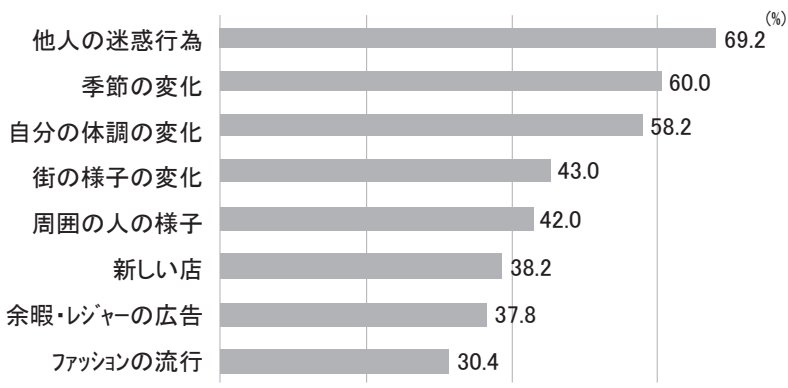

図 2-(1)電車内でよくすること

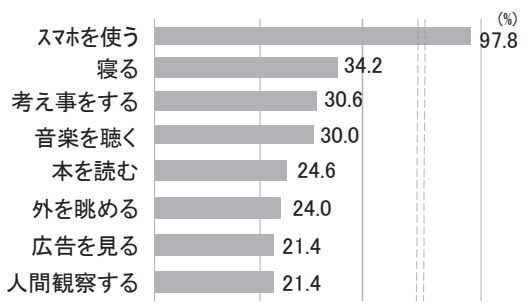

ソナルスペース」といい, 人はそれが確保されないと不 快になる。電車で端の席にすわるのは「パーソナルスペー ス」を確保するためであるが混雑した電車ではそれが確 保できずに不快になり，その不快感を紛らわすために外 の景色を眺めたり, 周囲の人を観察したり, 広告を読ん だりするということである（「混雑した電車では広告をよ く見る」と応えた人は「 $50.0 \% 」) 。$

次に「移動中の買物」に関する調査によると, 通勤の 「行き」では半数近く,「帰り」では約 7 割の人が週 1 回 以上何らかの買物をしていた（図 3-1)）。そして利用す る店は「行き」はコンビニ,「帰り」は食品スーパーとコ ンビニ, 次いで百貨店, ドラッグストア, 駅ビル SC, 買 うモノは「行き」は食料品と飲料,「帰り」はそれに加え て生活雑貨や衣料品など様々なジャンルに広がっていた。 また会社の行き帰りに「習慣的に買っているものがある」 という人が約 4 割いたほか,「会社帰りに衝動買いをす る」「色々な店を見て回ることがある」という人も相当 数いることがわかった（図 3-(2)，(3)）。

「習慣的買物」,「衝動的買物」,「探索的買物」といった

図 1-(2) 移動中の考え事

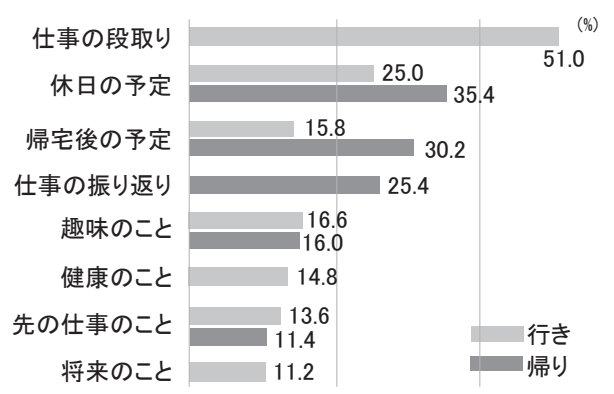

図 2-(2)駅や電車内での振る舞い

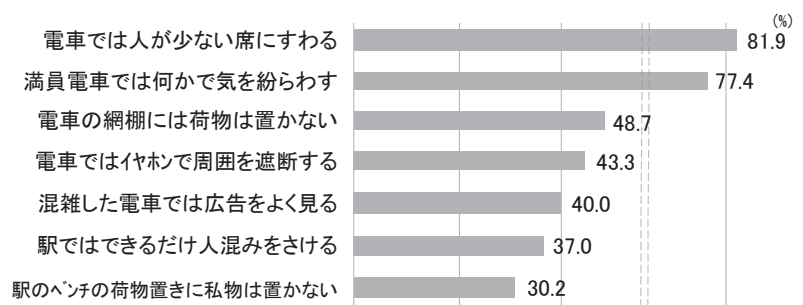


図 3-1

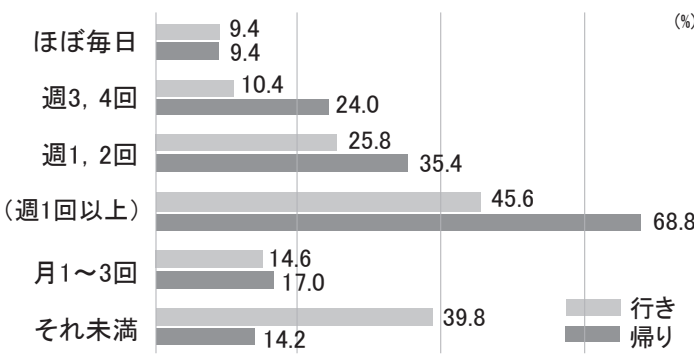

\section{図 3-(2)移動中によく買物をする店}

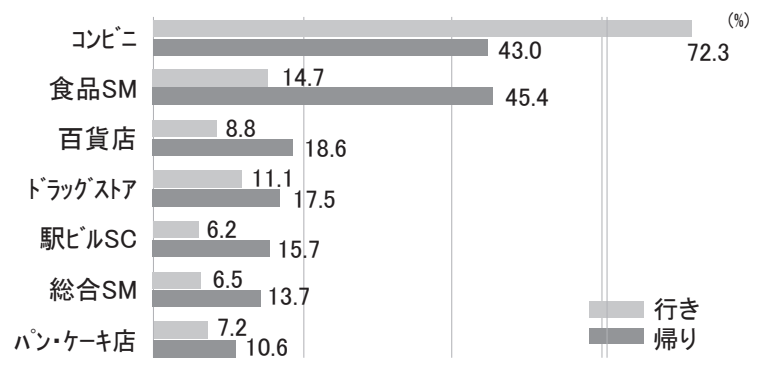

図 3-(3)移動中の買物行動パターン

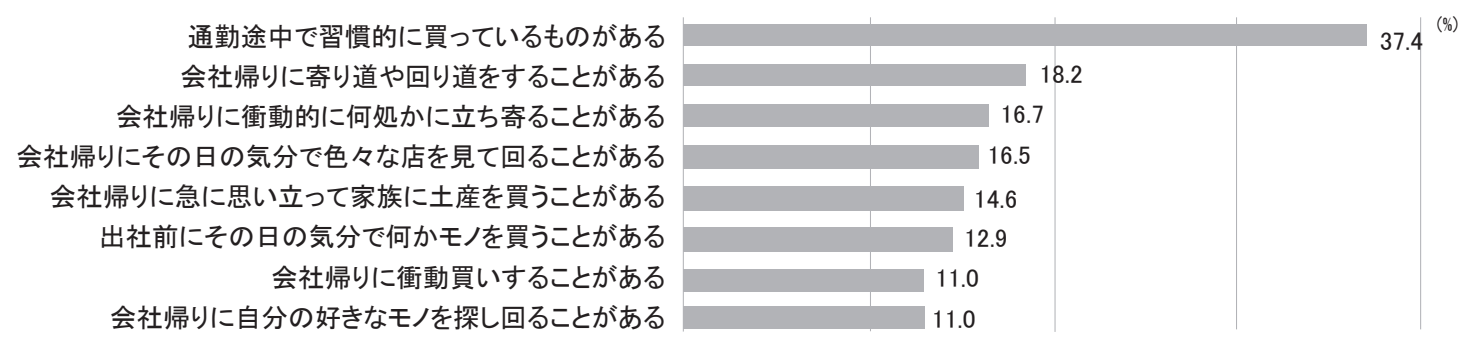

行動には各々違った意味合いが窅われた。通勤の行き帰 りでの「習慣的買物」は 50 代男性に多く，その理由は 「生活のリズムをつくるため」,「気持ちを切り替えるた め」，「買物をしないと物足りないため」などである。生 活者は日常を安定させるために自ら習慣を創り出し, そ れは繰り返されるほど強固なものになり，またモノに対 しても繰り返し消費することで「授かり効果」が生まれ て更に同じモノを買い続ける。また「衝動的買物」は 20 代から 40 代の女性に多く，「その日の気分で」といった 内的要因による場合と「欲しかったモノを偶然見つけて」 といった外的要因による場合が見られたが，都市部に勤 める移動者は毎日巨大なショッピングセンターの中を歩 いているようなもので衝動買いを促す外的刺激も多い。 そして自由気ままに店を見て回る「探索的買物」は特に 金曜日に多く見られ，それは週末が近づいて開放感が高 まるためであり，一週間を少しでも充実して終えたいと いう気持ちが働くためと思われる。

そして「移動中のスマホ利用」に関する調査では,「電

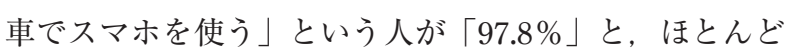

の移動者がスマホを利用していることが確かめられた。 そして今回の対象者の一日のスマホ利用時間は平均 90.3 分, 内移動中は 41.7 分で, 30 代以上の男性では移動中 の利用時間が移動中以外よりも長いことがわかった（図 4-(1)）。そして利用目的は「情報の収集や検索」が最も多 く，具体的には「ニュースを見る」，「気になっているこ とを調べる」，「仕事に関することを調べる」などで，移 動中が貴重な情報収集の時間になっていることがわかっ た。次いで多いのが「帰宅時間などを家族に連絡する」, 「SNS で友人とやり取りする」といった「情報の伝達や 対話」で，これは特に 20 代の女性に多く見られた。更 に「ゲームをする」，「音楽を聴く」といった「情報コン テンツの消費」を目的とした利用,「スケジュールの調 整」,「メールの整理」といった「情報の処理や整理」を 目的とした利用も見られ, 移動者が活発に情報を取り扱っ ている実態が捉えられた（図 4-(2)，(3)）。

スマホ利用に関する調査で，普段スマホを持ち歩いて いる人にスマホを持たずに出かけてもらったところ，そ の日は普段よりも活発に駅や街ナカの広告に目を向けた 
図 4-1 移動中の一日平均スマホ利用時間（性年代別）

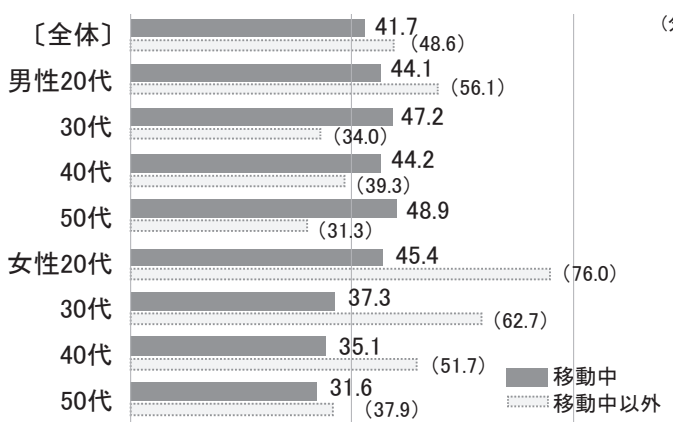

図 4-(2) 移動中のスマホ利用目的

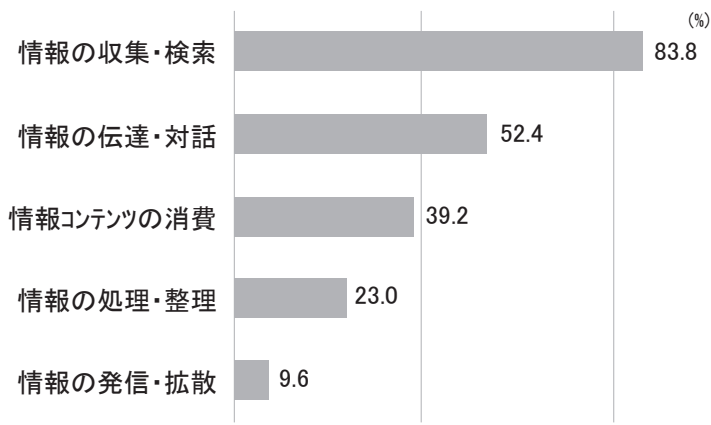

図 4-3) 移動中のスマホ利用内容

（情報の収集·検索）

ニュースをチェック

プライベートで気になっていること

仕事で気になっていること ECサイトを見る

(分)

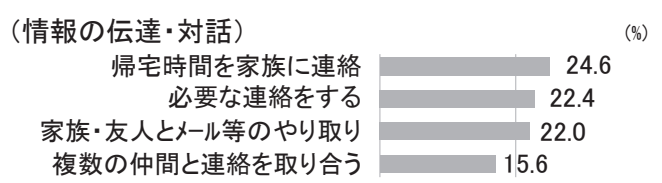

という実態が捉えられ，スマホを持つようになった現代 の移動者は以前よりも情報感度が高くなっていることが 窥われた。

\section{2. 移動中の心理}

「移動者が思っていることや感じている」など，移動中 の行動の背景にある意識や気分, 感情について定性調査 で洗い出した仮説をもとに検証を行った。

はじめに生活者に移動時間は必要か否かを問うてみた ところ「必要」と応えた人は「 $42.0 \% 」 と$ 半数に満たな かったものの移動時間に対する考えを問うてみると，「で きるだけ有効に使いたい」と応えた人が 7 割近くいたほ か,「気分を切り替えるのに必要」「「生活のリズムや安定 感が得られる」，「考え事をするのに必要」，「情報を整理 するのに必要」といったように必要とする理由が多く聴 かれた。また「自分を振り返る時間」や「アイデアを得 る時間」といった捉え方も見られ，人によっては移動時

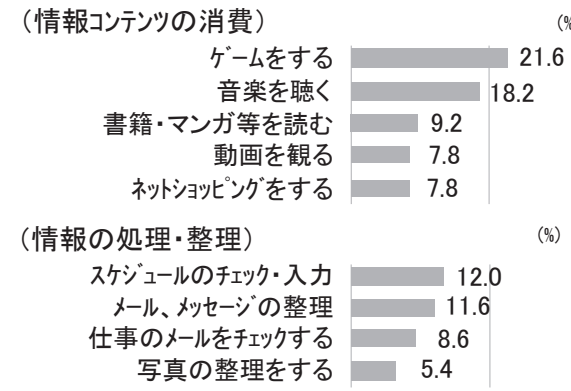

間が自分を振り返ったり新しい発想を得たりする機会に なっていることがわかった（図 5-1)，(2)）。

次に移動中の気持ちや思いについては,「移動中は他人 とのつながりを避けて自分の時間を楽しみたい」という 気持ちが「あてはまる」と応えた人が 6 割近くいたほ か,「ぼ抏っとしていたい」,「仕事から解放されたい」, 「気分をリフレッシュしたい」，「自由に過ごしたい」と いった応えが多く，これらからは日常の役割から解放さ れて自分の時間を気ままに過ごしたいという移動者の本 音が窅われた。また「平穏無事であってほしい」，「何も 変わったことが起こらないでほしい」といった声も聴か れ，毎日ルーティンを繰り返すことで安心感を得たいと いう思いがあることもわかった（図 6)。

また移動中の気分を「Uneasy（つらい，イライラ等）」, $\lceil$ Boring (憂鬱, うんざり等)」, 「Exciting (ウキウキ, 楽 しい等)」,「Relaxed (落ち着く, ゆったり等)」の要素で

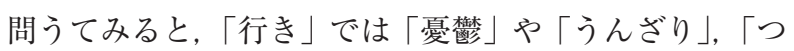




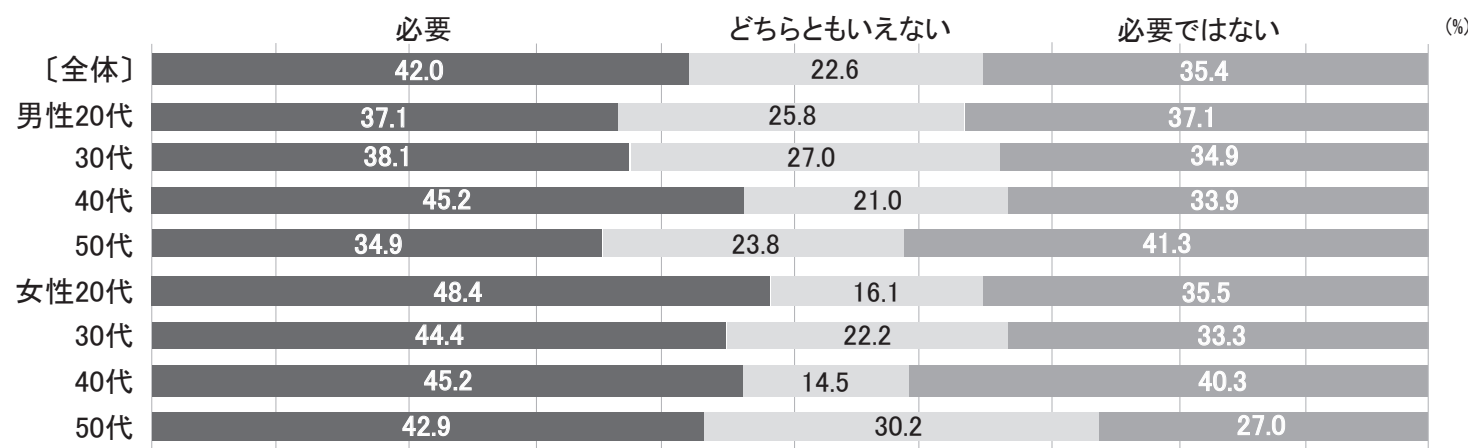

図 5-(2)移動時間に対する考えや意識

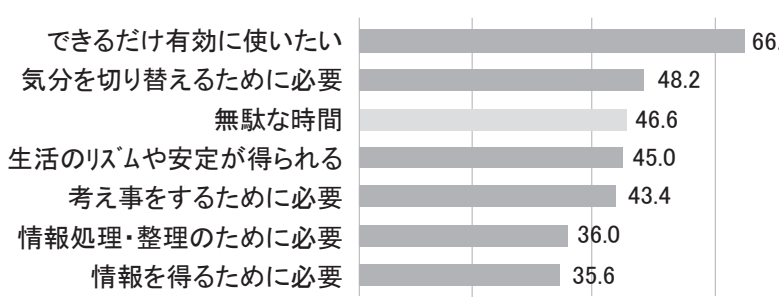

$(\%)$

自分の時間を楽しもうとしている 何もすることがない時間 自分を振り返る時間 自分にとって貴重な時間 素の自分に戻れる時間 発想やアイデアを得る時間 物事に集中するのに適した時間
$(\%)$

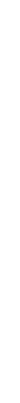

図 6 移動中の気持ちや思い（あてはまるもの）

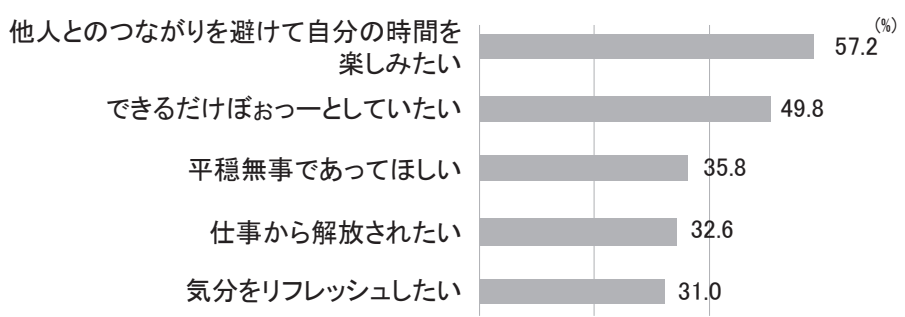

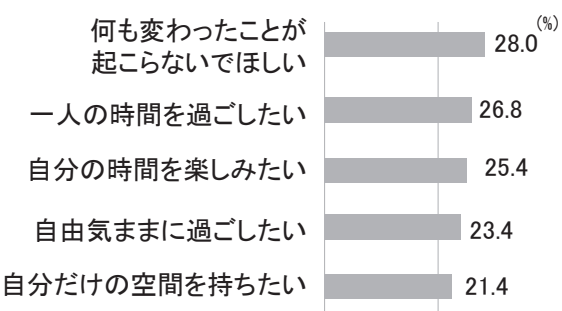

らい」といった「不快」な気分の人が多く，「帰り」では $\lceil$ Exciting」や「Relaxed」などの「快」な気分の人が多く なるものの「Uneasy」や「Boring」な気分でいる人も少 なからずいることがわかった。そして移動中に求める気 分では「行き」「帰り」ともに「Exciting」な気分よりも 「落ち着く」,「安らぐ」など,「Relaxed」な気分を求める 人が多いことがわかった。「Boring」は覚醒水準が低い不 快な気分,「Uneasy」は覚醒水準が高い不快な気分で, 人は「Boring」の時は「Exciting」を求め (刺激欲求), $\lceil$ Uneasy」の時は「Relaxed」を求める (安楽欲求) (図 7-(1), (2))。同じシチュエーションであっても「刺激欲 求」をもつ時と「安楽欲求」をもつ時があり, 従って通 勤の行き帰りでもその時々で生起する欲求も異なるであ ろうが, 先に述べた移動中の気持ちや思いも合わせて考 えると移動者は「刺激欲求」よりも「安楽欲求」を感じ ることが多いと思われる。 


\section{図 7-1 移動中に求める気分}

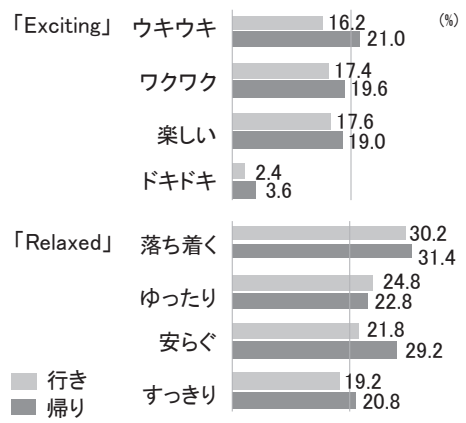

\section{III. 消費者行動研究としての本研究の意義}

\section{1. 移動中の快楽消費}

消費者行動研究としての今回の研究の意義は移動中の 消費行動の多くが「快楽消費」であることを捉えた点に ある。Horiuchi（2001）によると「快楽消費」とは，商 品やサービスを消費することで得られる快楽の経験が原 動力になっている消費行動のことで，これに対し実用的 価值に立脚する消費は「実用消費」である。「実用消費」 における消費者は合理的な購買動機を持ち理性的に判断 する論理的思考者であるが，「快楽消費」は感情に従って 買物をする非合理的な消費者を想定していて，移動者は この「快楽消費」を行う非合理的な消費者としての性格 が強いということである。

快楽消費の要素には「繰り返す安心感」,「発散」,「自 発性」,「認識された自由」,「新奇性」,「発見」,「非日常」 などがある。「繰り返す安心感」とは「習慣的になった行 動は慣れによって快楽をもたらす」といった意味である が，今回の調査で聴かれた「出社前にいつもの店でいつ もの飲み物を買わないと落ち着かない」,「毎日のルーティ ンを崩さないことでその日の仕事をいつも通りにうまく いかせたい」といった「習慣的買物」についてのコメン トからは，まさにこの「繰り返す安心感」という快楽を 求める移動者の心理が窥われる。

次に「発散」とは「消費が発散の機会になり暮らしに メリハリが生まれることで快楽が得られる」,「自発性」

\section{図 7-(2) 気分と欲求の関係}

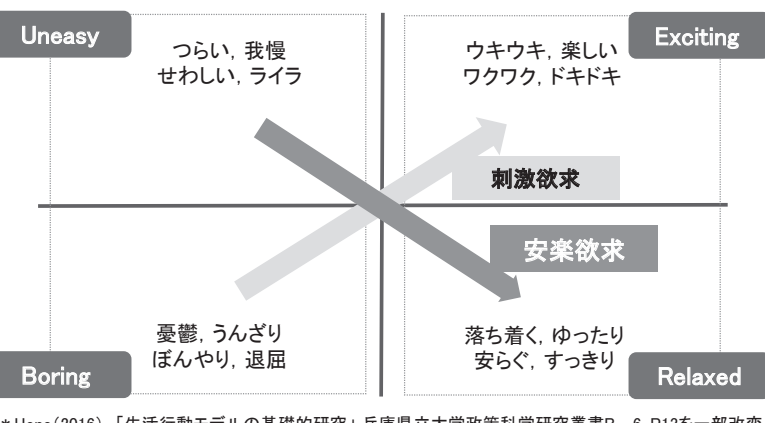

や「認識された自由」とは「強制や義務によってではな く自由意志で，または自分勝手に消費することで快楽が 得られる」といった意味で, 移動者は主に「衝動的買物」 によってこれらの快楽を得ていると思われる。衝動買い は自由気ままな行動であり, いつもストレスや緊張感を 抱えている生活者にとってはそれを発散できる魅力的な ものである。また衝動買いという行為は自発的な行為で あり，自分が主導権を握り周囲を支配している感覚，す なわち「コントロール感覚」が得られる行為である。会 社や家庭では周囲に動かされ自分中心に物事が進められ ないことが多い生活者は移動中に衝動買いをすることに よって, この「コントロール感覚」を取り戻していると 思われる。

そして「新奇性」とは「珍しい買物の対象物が快楽へ の刺激になる」,「発見」とは「掘り出し物や予想外のモ ノを発見した喜びから快楽が得られる」「非日常」とは 「消費を通じて非日常的な空間に浸ることで快楽が得られ る」といった意味で, 移動者はこれらの快楽を「探索的 買物」によって得ている。買物がもつレジャー性の要素 はこの「探索性」であり, 欲しいと思っていたモノを偶 然見つけたり掘り出し物を見つけたりといったことへの 期待感から買物の楽しさが生まれ, 期待が叶えられた時 には大きな快感を得て，その経験がまた同じ行動を促す。 今回の調査では「仕事が早く終わった日にいろいろな店 を見て回るのは自分にとって非日常」といったコメント も聴かれ，移動者がこうした目的性のない探索的買物行 動をするのは，日々のルーティンを繰り返す中にも新し 
い出会いや発見を求めているからであり，非日常的な感 覚を得ようとしているためと思われる（図 8)。

「快楽欲求」が生じた時に消費者の中で買物行動への内 的な準備状態が形成され，それが買物行動の動因となる が，今回の調査で実際に行われた買物を見ると「繰り返 す安心感」「発散」,「自発性」といった快楽の要素が動 因として特に多く認められた。そして実際の買物が行わ れるのはこれらの動因が生じると同時に，それを実現で きる環境要因，すなわち「誘因」が存在しているからで ある。環境要因とは移動経路上に対象となる店があった りモノが並んでいたり，また時間的余裕があるといった ことであるが，逆にいえば「動因（快楽欲求）」が生じた にも関わらず，それを実現できる「誘因（環境要因）」が 存在しなかった場合には買物行動は実現しない。そのよ うな時には，生活者はその場で行動を起こすのではなく 次の休日などに欲求を満たすための時間をつくり, 欲求 が满たされる場所や施設を見つけて行動することにな る。従って移動者とコミュニケーションをとるにあたっ ては移動者の「欲求」を捉えた上で，その場での行動に 影響を与えようとするのか，それとも後の行動に影響を 与えようとするのかを区別して考える必要がある。

\section{2. 移動中のスマホ利用と消費行動}

本研究の消費者行動研究としての意義のもうひとつ は，常にスマホを持ち歩く現代の移動者の消費行動に影 響を与える情報提供に関する新しい知見を得たことであ る。スマホの普及により移動中の情報環境は大きく変化
し，それによって生活者の移動中の過ごし方や移動時間 に対する意識も大きく変化した。スマホを携帯するよう になったことで移動中にできることが以前に比べて格段 に増え，移動時間は「つぶすもの」から「使うもの」に 変わり，その使い方も多様化したということである。中 でも電車に乗っている時にスマホを利用して情報を収集 する移動者は多く，これは移動者とうまくコミュニケー ションすることでその行動に影響を与える可能性が広 がってきたということであり，今回の調查においても移 動中での情報収集が購買行動に直接結び付いているケー スが見られた。

例えば，あるSNS で得た情報がきっかけとなって次か ら次へと SNS をハシゴし，それがショッピングサイトで の情報検索やリアル店舗での商品購入，更には知人との 情報共有といった行動につながっているケースが見られ たが，これはまさに移動中に「気づき」から「訴求」「調 查」,「行動」,「推奖」までのカスタマージャーニーが起 こっているということである。また今回の調査では電車 でネットショッピングをするのは約 1 割の人に限られて いたが，そのユーザーはかなり高い頻度でそれを利用し ていた。特に利用者が多いのは 30 代女性で（「行き」の 電車では「21.0\%」,「帰り」では「14.5\%」), 移動時間 を利用して通勤のための洋服や化粧品などを購入すると いうことであるが，一度利用すると購入履歴が残り次に はより短時間で買物を済ますことができることで，その 利用が繰り返されるということである。またネットショッ ピングでも衝動買いによって気晴らしをするといったケー

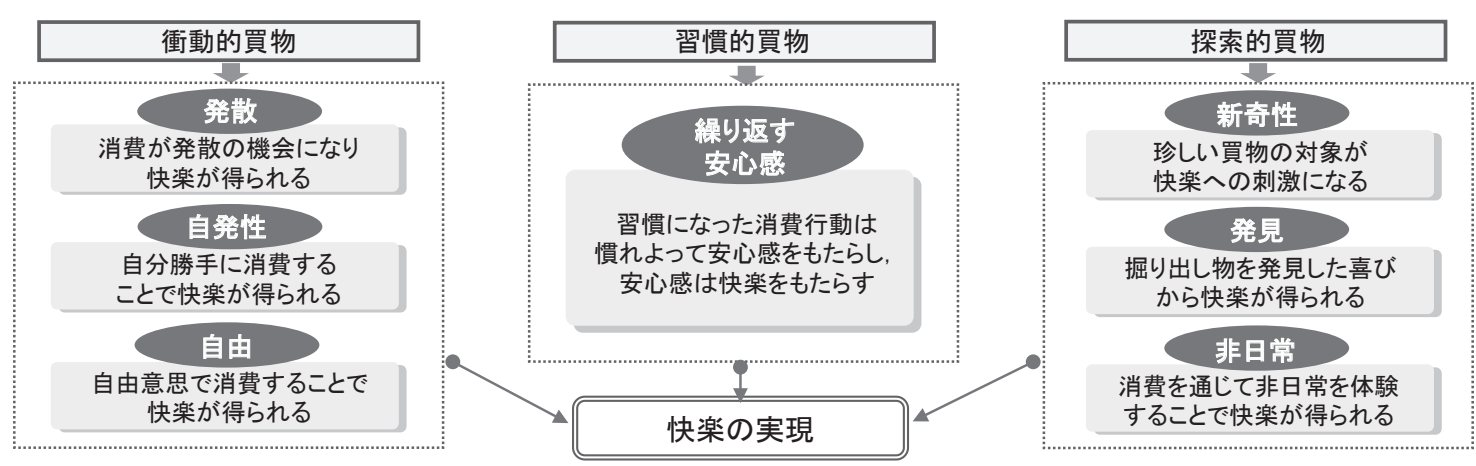


スや,「行き」の電車で情報検索して「帰り」の電車で購 入するといったケースなども見られた。

通勤電車でスマホを用いてよく情報収集する内容を問 うと，「買物に関する情報」と応えた人は「行き」では

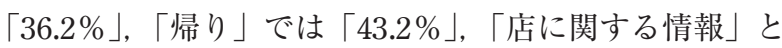
応えた人は「行き」では「23.6\%」,「帰り」では「26.6\%」 であった。そしてそれを年代別で見ると 20 代女性では 「帰り」に買物情報を検索するという人が「61.9\%」，30 代女性でも「56.5\%」であった（図 9-11)。すなわち特に 20 代，30 代の女性の多くが移動中に買物のことを考元， その情報を自ら取りにいっているのである。

SNS や情報サイトの利用者には常に情報過多の問題が つきまとう。すなわち受信はされても目にされなかった り注目されなかったりするという問題があり，それは今 や多くの生活者にあてはまる。そして情報過多を感じて いる利用者は直近の情報を選別して見たり読んだりする 傾向があり，受信してから時間が経過した情報は見過ご される可能性が高い。すなわち情報を送る側からすると タイミングによって配信した情報がどの程度の深さで受 け入れられるかが違ってくるということである。これま で述べてきたように電車では多くの移動者が SNS や情報 サイトを起動させている（図 9-2)）。すなわち電車内の 移動者は情報をすぐに受け取れる状態にあり，且つ「今 届いた情報」であるが故にそれに注意を払う可能性が高 いということである。買物情報やレジャー情報など，移 動者が関心を持っている情報を，位置情報システムを用 いて乗車中の移動者に届けると, それはしっかり受け取

図 9-1)電車内での「買物情報の検索」(性年代別)

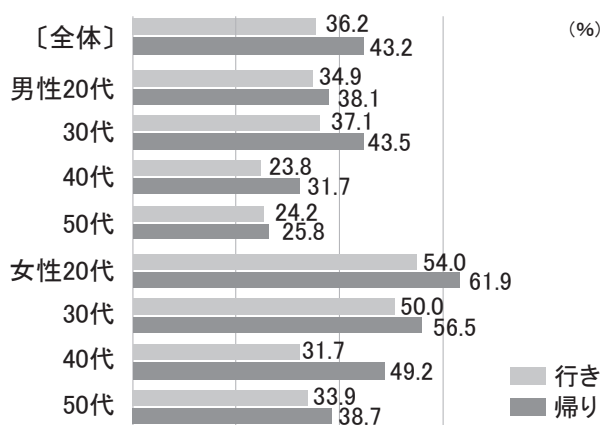

られ, 買物やサービス利用などの行動を喚起できる可能 性も高いということである。

\section{IV. まとめと今後の研究課題}

\section{1. 移動者の「ホンネ」}

今回捉えた移動者の心理は「移動時間を有効に使いた い」,「自分だけの時間を楽しみたい」「気分を切り替え たい」,「安心感を得たい」,「その日の充足感を高めたい」, 「変化がほしい」,「非日常を求める」,「安楽を求める」な どであるが，これらには相反する意味が含まれている。 すなわち「移動時間を無䭾にしたくない」といった意味 合いと「移動中はぼんやりと過ごしたい」といった意味 合いが両方含まれているということであるが, 前者の「無 䭾にしたくない」という思いは無䭾にできない事情を抱 えているからであり，それが必ずしも「ホンネ」とは思 えない。今回の調查で日常生活の繁忙感について問うて みると約 8 割の人が「忙しいと感じる」と応え，また 「とても忙しい」と感じている人ほど「移動時間を有効に 使いたい」と応えた人が多く, 同時に「ぼんやりと過ご したい」と応えた人も多かった。すなわち現代の多くの 生活者には常に「忙しい感覚」があり, それ故移動時間 も無駄にできないという意識あるものの，同時に「ホン ネ」として「移動時間くらいはぼんやりと過ごしたい」 という思いを持っているということである。複数の社会 に属し各々の役割を担いながら日常を過ごしている現代

図 9-(2)＼cjkstart電車内でよく利用するアプリ（サイト）

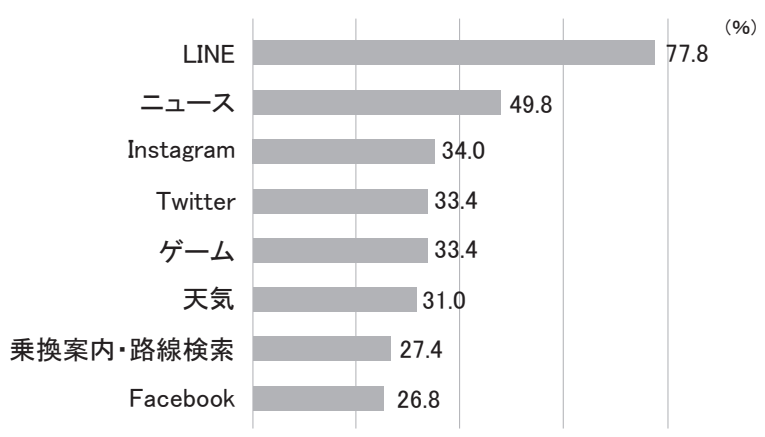




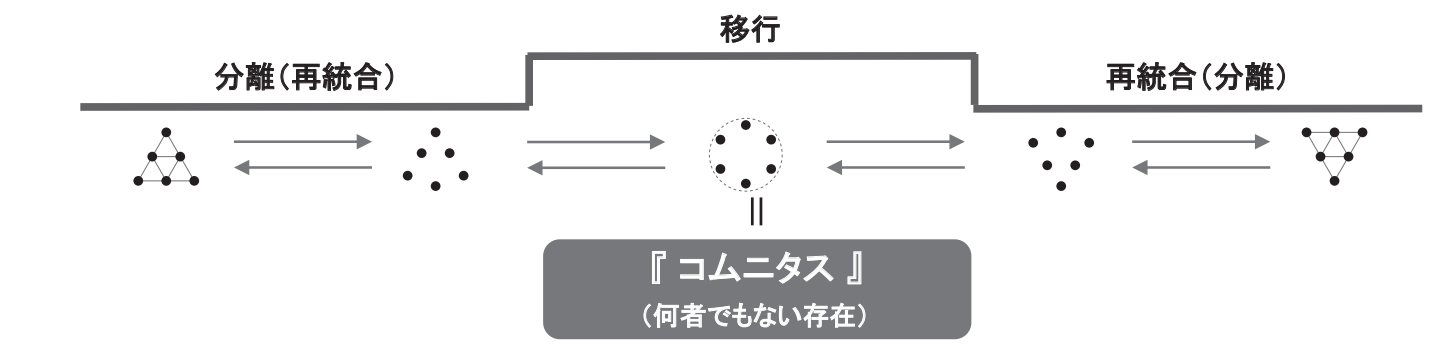

社会的役割からの解放 / 緊張緩和 / 気分切り替え・リセット / 自己の再認識

*「通過儀礼」はフランスの人類民俗学者A.ファン・ヘネップが提唱した用語(Gennep (1909))。人の生涯における誕生、成人などの各段階を通過する際に行われる儀礼で、「分離」、「移行(過渡)」、 「再統合」のろつの局面からなる。その後、アメリカの文化人類学者であるヴィクターターナーがそのプロセスの中の「移行(過渡)」の概念を発展させ「コムニス」とい概念を提唱。

の生活者の多くは, 会社と家庭の中間にある移動中にい ずれの役割からも解放されて「素の自分」に戻りたいと いう欲求を持っているのではないか。移動をある役割か ら別の役割に移行する「通過儀礼」と考えると, 移動者 が求めているのはその途中にある「コムニタス」の状態, すなわち「いずれの社会にも属さない意識状態」であり， そこで移動者は「何者でもない存在」になって日常の緊 張を和らげ，自分をリセットし，自己を再確認し，そして 個人としての自分と社会的存在としての自分のバランス を調整しながら次の役割に備えていると思われる（図 10）。

\section{2. 今後の研究課題}

本研究の理論的成果は現代の生活者にとっての移動の 意味合いと移動者の「ホンネ」を捉え, 移動中の消費行 動に関する新しい知見を得たことである。そして次には 「どういったメッセージが移動者の心を動かし, どのよう なコミュニケーション手法を用いれば移動者の行動変容 を促せるのか」という問題に具体的にアプローチする必 要がある。そのために移動者研究の第二段階では, 電車 内や駅ナカ商業が充実した駅構内など，特定の移動空間 にいる移動者にメッセージを送りその行動変容の実態を 捉えるといったことや，特定のコンテンツを移動者に提 供しその反応の程度を測定するといった実証研究に取り 組む。それによって移動者に対する効果的なコミュニケー ション手法や移動者の満足度を高めるための移動空間設 計の具体的方策を導き出したい。

\section{References}

Corballis, M. (1843). The wandering mind: What the brain does when you're not looking. Chicago: University of Chicago Press.

Gennep, A. V. (1909). Les rites de passage: Etude systematique des rites. African Affairs, Volume IX, Issue XXXIII. London: Oxford Academic.

Horiuchi, K. (2001). Kairaku shohi no tsuikyu. Tokyo: Hakutou shobou. (堀内圭子 (2001)。『快楽消費の追及』白桃書房) (In Japanese)

Nakano, O. (1997). Media ningen: Communication kakumei no kouzou. Tokyo: Keisou shobou. (中野収 (1997).『メディア 人間一コミュニケーション革命の構造』勁草書房) (In Japanese)

Ueno, K. (2016). Seikatsu koudou moderu no kisoteki kenkyu. University of Hyogo Monograph, B-6.（植野和文 (2016). 「生 活行動モデルの基礎的研究」『兵庫県立大学政策科学研究叢 書』B-6) (In Japanese) 